\title{
THE CIVILIAN CONSERVATION CORPS
}

\author{
By \\ Crosby A. HoAR \\ U. S. Forest Service, Amherst, Mass.
}

$\mathrm{T}$

HE Civilian Conservation Corps was authorized by Congress within a month after President Roosevelt took office. It was one of the first steps taken in the administration's program of economic recovery. The purposes of the C.C.C. were clearly stated in the enabling act of March 31, 1933, as follows: "That for the purpose of relieving the acute condition of widespread distress and unemployment now existing in the United States, and in order to provide for the restoration of the country's depleted natural resources and the advancement of an orderly program of useful public works, the President is authorized," etc. The C.C.C. was therefore established (1) to relieve unemployment, and (2) to restore depleted natural resources.

Undoubtedly relief of unemployment was the dominant reason. The elaborate precautions taken to enroll a certain element in the unemployed population (viz. young men from 18 to 25 years of age); their enrollment in accordance with quotas based upon population rather than upon the amount of conservation work to be done in each locality; and the financing of the project from Emergency funds with but little question when or whether it would be self-liquidating, clearly show that the need of supplying work was the first consideration.

On the other hand, the purpose to restore the country's depleted natural resources was by no means a mere phrase. The President had shown himself unusually familiar and sympathetic with the aims of forestry and other forms of conservation. As an Associate member of the Society of American Foresters he had sent greetings to foresters assembled in convention, addressing them as "fellow foresters," and expressing the hope that they would presently have larger opportunities for accomplishment. When representative foresters were called to the White House, soon after the passage of the Act which authorized the C.C.C., the President told them in effect that he expected results in the woods, as well as the benefits which would flow from providing employment. The Act was a challenge to conservationists in general, and to foresters in particular, to show what they could do when given money and man power far beyond anything they had ever experienced, and perhaps beyond their wildest dreams.

Quoting again from the Act, the President was authorized, "under such rules and regulations as he may prescribe and by utilizing such existing departments or agencies as he may designate, to provide for employing citizens of 
the United States who are unemployed, in the construction, maintenance and carrying on of works of a public nature in connection with the forestation of lands belonging to the United States or to the several States which are suitable for timber production, the prevention of forest fires, floods and soil erosion, plant pest and disease control, the construction, maintenance or repair of paths, trails and fire lanes in the national parks and national forests, and such other work on the public domain, national and state, and Government reservations incidental to or necessary in connection with any projects of the character enumerated, as the President may determine to be desirable," etc. This was a broad program. Although the text quoted above confines the work to "public domain, national and state" a further provision of the Act authorized its extension to lands owned by counties and municipalities and lands in private ownership for such purposes as preventing and controlling forest fires, and attacks of forest tree pests and diseases, and work necessary in the public interest to control floods. The President was also authorized to house the persons employed (i.e., the enrolled members of the C.C.C.) and to furnish them subsistence, clothing, medical care and cash allowance.

These provisions, with several minor ones which I have omitted, constituted the authorization for the C.C.C. under the Act. The President personally considered and shaped the basic plans for organizing the work. He fixed the size of the work camps at approximately two hundred men each, to the disappointment of many foresters who would have preferred to have the camps smaller and more flexible. The President decided that the U.S. Army should be responsible for the housing, subsistence, discipline, and welfare of the enrolled men. This decision, which made necessary the closest possible coroperation between the Army and other governmental agencies, has been the cause of some difficulties, yet it lifted from the shoulders of the operating agencies a number of burdens which they were ill prepared to assume, and allowed them to concentrate upon the tremendous task of directing the field work. Besides the Army, the administration of the C.C.C. was divided between the Department of Labor, the Department of Agriculture, (through the Forest Service), and the Department of the Interior (through the National Park Service and the Indian Department). To co-ordinate the activities of the several departments the President appointed Mr. Robert Fechner as Director of Emergency Conservation Work.

To the Department of Labor was assigned the task of selecting 250,000 men between the ages of 18 and 25, drawn from the several States and Counties, according to quotas, based upon population. The Department of Labor called to its aid in this work local relief agencies. The men selected had to be unemployed at the time of enrollment and in many localities, were 
taken wholly from local relief lists. The terms of employment called for them to work 40 hours a week, compensation to be their subsistence and clothing and $\$ 30$ per month. Those who had dependent relatives were required to allocate to such relatives $\$ 25$ per month, so that the benefits of the C.C.C. were extended beyond the enrolled men, to those dependents who shared their earnings.

It was early recognized that the largest quotas of enrollees would come from the cities while the work projects would be chiefly in sparsely populated counties, where the quotas were small. To some extent local labor was accustomed to depend upon securing work in National and State forests and parks, and had a claim upon such work. To import large numbers of city boys would certainly arouse resentment in the country districts unless the latter were given larger representation than their quotas provided. Also local work. ers were more familiar with woods work than were the city boys and hence more valuable. For these reasons the operating agencies were authorized to enroll a number of local experienced woodsmen, averaging about sixteen per camp. These men did not have to be between the ages of 18 and 25 , and often were older men who presumably were qualified by maturity and experience to help lead and train the younger enrollees. A subsequent development was the enrollment of 25,000 war veterans who were established in separate camps instead of being mingled with the younger men. Thus the total number of enrolled men finally reached 300,000 .

To the War Department was given the task of enrolling the men as they were selected, and placing them in concentration camps where they could be inoculated against smallpox and typhoid, equipped with clothes and given a few weeks of physical training and hardening to fit them for the work they were to do. This hardening process was considered necessary in view of the fact that many of the young men had never done manual work or had been unemployed for so long a time that they were not in condition to do hard work. To the War Department also was assigned the duty of building and operating the camps. The War Department had to furnish all tents, beds, and camp equipment of every sort, and all food supplies. Each camp was placed in charge of a Camp Commander, who was given another commissioned officer and one or more non-commissioned officers as assistants. The Camp Commander was made responsible for discipline, welfare, recreation, and in short had full control of the men while they were in camp. Medical officers were provided at an average of one for every three camps.

To the Forest Service and the Park Service were given the responsibility of planning and accomplishing the conservation work for which the camps were established. Forest camps were located on National Forests and State 
Forests. Park camps were located on National Parks and State Parks. Many camps also were located on private land, particularly where erosion control was the objective. The administration of the field work, although centered in the United States Forest Service and the United States Park Service, was to be carried out through the State Forest and Park agencies in respect to the camps which were classified as State camps; that is those which were not on lands owned by the Federal Government. Thus after the selection of men had been accomplished by the Department of Labor, the operating control was shared by the Army on the one hand and the Forest Service and the Park Service on the other hand; the Army being responsible for maintaining and caring for the men, while the Forest Service and the Park Service were responsible for all field work.

To direct the field work, it was necessary to have a considerable overhead and this overhead had to be hired on a temporary basis because practically no regular employees of the Forest and Park Services could be spared for work in the C.C.C. camps. Immediately following the announcement of the President's policy for the administration of the Act, the Forest Service and the Park Service set about hiring camp superintendents for all camps on Federal lands, and a very considerable number of foremen and "facilitating personnel" such as tractor operators, blacksmith clerks, mechanics, etc., etc. Similar overhead for the State camps was hired by the States subject to Federal approval.

To guide the selection of these employees, specifications were drawn covering the qualifications for each overhead and facilitating position, and rates of pay were established for each position. These rates varied slightly in different parts of the country, because of an attempt to correlate them with local wage scales. As an example the rates established for National Forest camps in the Lake States were as follows:

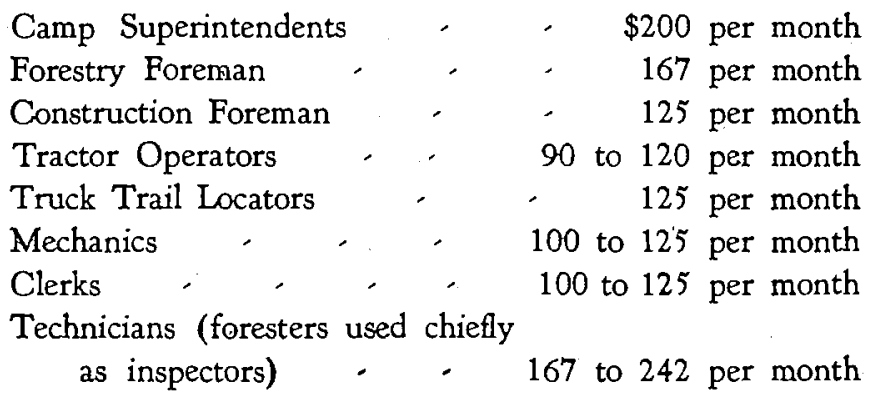

All these rates were subject to the $15 \%$ deduction which was being applied to all Federal salaries. Not all camp superintendents were technically trained foresters, but technical training was required for superintendents of camps 
where silvicultural work was the dominant purpose. Elsewhere superintendents might be men who were experienced in road building, logging, or the construction of buildings, telephone lines, and other forest improvements. Likewise the ratio of forestry foremen to construction foremen in each camp varied according to the kinds of work which the camp was to undertake. In general the National Forest camps contained from three to eight forestry foremen apiece, an aggregate number which almost exhausted the supply of qualified foresters. Since the Federal camps were the first to be established, the States claimed with some justice that there were insufficient foresters left available to them to meet their needs. It was necessary to relax the specifications for forestry foremen to secure enough for the later State camps, and even then some lacked foresters where they were badly needed. It is only fair to add that some of the camps first established had more forestry foremen than they really required, so that a better distribution of them would have been beneficial to all parties.

The C.C.C. has been the economic salvation of many foresters. Hundreds of them were unemployed, and eagerly accepted positions as Camp Superintendents, Forestry Foremen, or Technicians with inspectional duties. There was little disposition to quibble about assignments or rates of pay. Among these men were many recent graduates who had had little or no employment in their profession, and could not find any. Not a few had been earning their livelihood as engineers or landscape architects, or in enterprises less closely connected with their professional training. Some had been outstanding figures in forestry, who had lost their positions through political or economic changes. All of these foresters found themselves suddenly in demand. Many of them were hired by telegraph by someone who knew only that they were foresters out of work. Many of them accepted, with only the vaguest knowledge of what they were to do, or where they were to go.

To the credit of these men and their professional training, most of them have made good in the C.C.C. Those who have failed include a few misfits such as are met in every profession, and a larger number who were not adapted to the duties of foremen. In fact, the greatest fault to be found with the forestry foremen is that too many of them were young, inexperienced, and lacking in the qualities of leadership.

The division of responsibility between the United States Army on the one hand, and the Forest Service or Park Service on the other hand, is brietly expressed in the following statement:

The Army was to do these things:

1. Build and equip 200 man work camps at the locations specified by the operating services. 
2. Receive men at conditioning camps and transport them to the work camps.

3. Feed the enrolled men and others quartered at the camps, provide medical attention and hospital care, handle compensation cases of enrolled men, and maintain discipline in the camps.

4. Provide clothing and camp equipment as needed.

5. Pay camp allowances and all expenses incident to operation of camps including transportation of camp supplies and camp equipment to the camps.

6. Pay all bills properly payable from Emergency Conservation Funds. This meant that the Army was a disbursing agent for the operating agencies, (that is the Forest Service and the Park Service).

7. Inoculate supervisory and facilitating personnel as well as enrolled men against typhoid and smallpox.

The Operating agencies were to do the following things:

1. Select camp locations.

2. Transport the men from the work camp to the job and back.

3. Furnish technical supervision of the work projects and plan and direct the work with exclusive authority in the field.

4. Purchase equipment and material for doing the work except as equipment could be provided from Surplus Government Stocks.

5. Voucher salaries of all supervisory and facilitating personnel, traveling expenses, and costs of materials and equipment purchased for the C.C.C. work for payment by the Army.

6. Fix hours of work in Emergencies, such as fire fighting.

7. Cooperate with Aimy officers in instituting suitable action concerning enrolled men who were incompetent or insubordinate.

The division of responsibility between the Army and the Operating Services was essentially clear, but the very fact that responsibility was divided made necessary the heartiest and most understanding co-operation on both sides. Consider the somewhat different purposes and viewpoints of a Camp Commander, assigned by the Army, and a Camp Superintendent, appointed by the Forest Service. They are thrown together in a camp of two hundred enrollees, of whom a few are local woodsmen, but the majority are inexperienced boys. The camp commander is a captain or a lieutenant, either a regular or a reserve officer. He receives his instructions from military sources, but his camp is not a military camp and his men are civilians. He is responsible for the conduct of the camp and the welfare of the men in it. In-so-far as its purpose is human rehabilitation, discipline, morale, physical and mental 
improvement-the whole sociological aspect of the enterprise--the job is his. He has only a casual knowledge of forestry, and no special interest in it. His success will be gaged by the kind of camp he keeps, the kind of meals that are served, the smoothness with which the camp runs, and the adequacy with which he cares for his men in every way. The work superintendent, the foresters and other foremen are quartered in the camp, but are not under his direction. They are distinctly non-military-possibly a little suspicious of military methods. Some of them dress carelessly. Their concern is not with the camp, but with the work outside it. The Camp Commander wants plenty of men to perform camp duties, since the camp is his responsibility.

The Camp superintendent, on the other hand, has no responsibility for the camp. His interest in it is that he and his foremen shall be well housed and fed; that he shall have a suitable office and a storeroom for his tools and equipment. He wants to have as many as possible of the best men for his working crews; to some extent he is in competition with the Camp Commander for them. The interests of the field work may call for side camps; for the retention of men in camp on Sundays and holidays in hazardous fire weather to constitute fire crews; for deferment of leave due the men during tree planting time. The Camp superintendent will be judged by his success in accomplishing field work, and his efforts must be directed towards that end.

These differences in viewpoint between the Camp Commander and the Camp Superintendent reflect the differing responsibilities of their parent organizations, the Army and the Forest Service. Unquestionably there are drawbacks to any such division of responsibility, but it is doubtful whether the President's purpose could have been fully accomplished without it. The C.C.C. has done much more than employ 300,000 men; it has also looked out for their welfare to an unusual degree. That has been one task of the Army. To house, clothe, supply and transport these men, and to pay the bills incur. red, has been a big, difficult job, excellently performed. Had these duties been thrown upon the operating agencies, in addition to the direction of the field work, serious delays and lowered efficiency must have resulted. The Army and the operating agencies have worked together, under the direction of Mr. Fechner, with a fine spirit of co-operation. Each has made concessions necessary for the best general results. On a smaller scale, with somewhat less emphasis upon the welfare phase, the operating agencies might carry on alone.

The classes of work which were authorized included the following:

1. Fighting and preventing forest fires. It was allowable to keep small suppression crews in camp awaiting fire calls in times of critical hazard, and 
to use individual members of the C.C.C. for lookout and fire guard duty where they: could replace regular employees.

2. Construction and reconstruction of telephone lines, fire breaks, lookout towers, and buildings for administration and protection of the forest lands.

3. Fire hazard reduction including snag flling and clean-up of slash and debris along roads, trails and fire breaks, or through large bodies of slash. This included the piling of slash and debris to be burned when conditions made burning safe.

4. Clearings, water development, construction of sanitation structures, etc., on camp grounds on which the public is concentrated for the sake of fire prevention.

5. Construction of trails and truck trails. Truck trails are low-standard roads justified solely or chiefly for fire control and not designed to carry heavy traffic.

6. Construction of emergency landing fields where justified in fire patrol.

7. Simple works of erosion and flood control.

8. Planting, seed collection, and tree nurseries.

9. Insect and tree disease control.

10. Rodent control, particularly where needed to safeguard plantations.

11. Forest and timber surveys.

12. Timber stand improvement including weeding, release cuttings, thinning and pruning.

13. Forest research.

These approved projects include practically all the important types of work needed on National and State Forests. In a broad way they divide into construction work and forestry, using the latter term to include the weedings, thinnings, release cuttings, etc., which may be lumped under the term "cultural work;" the control of tree diseases and insect pests; and also forest surveys and research projects. During the first month of the project, silviculture seemed to receive less attention than construction projects. One reason may be that in spite of the employment of thousands of technical foresters as foremen, and of supervision by a corps of trained foresters, the construction projects were closer to the experience of the average man and were more easily understood and carried out than were the forestry projects, especially cultural cutting. Few foresters have had much experience in applied silviculture, and where there is doubt as to the best methods, there is hesitancy to undertake cultural cuttings on a large scale. A further reason has been that cultural cuttings created a large amount of unsaleable debris which required 
disposal by burning, and that of course only at safe periods, preferably in winter. At the present time particular emphasis is being placed upon cultural work because it did lag in the early months of the project and because the winter season is most favorable for its accomplishment.

In the National Park and State Park camps the work is aimed chiefly at improving recreational facilities. These include such things as roads, trails, bridges, parking places, bathing beaches, camp grounds, small artificial lakes, sanitary facilities, and many other improvements, in which the cost of materials is not too great. In some sections of the country erosion camps have been established, seeking by building small dams to check the spread of gully erosion in clay soils. A relatively small number of camps have been placed upon Indian Reservations and Military Reservations, under the supervision of the Indian Service and the military authorities. There is considerable overlapping of forest and park projects, especially upon State Forests, where the recreational purpose is combined with forestry. In such cases the dominant projects serve to classify the camp as a Forest camp or a Park camp.

Figures summarizing the work accomplished by the C.C.C. are compiled at the end of each month, and are available to those who want them. It seems more to the point to venture some impressions, even though necessarily based upon incomplete information, as to the degree of success which has been attained.

From the sociological standpoint, the success of the C.C.C. could hardly be questioned. Some 300,000 young men have been taken off the relief lists, freed from the evil consequences of enforced idleness, and permitted to earn their living and to contribute substantially to their dependent relatives. They have been remarkably healthy. Average gains of 10 to 12 pounds in weight have been recorded for such large numbers as to leave no doubt that they have been well nourished. One has only to see them to know that they are in a healthful environment. Their mental attitude is generally good. At the outset some of the enrolled men resented the low wage of $\$ 30$ per month, forgetting perhaps that subsistence was free. Boys who were accus tomed to city wages thought themselves underpaid, and showed it by indif ference toward their work. That attitude has largely disappeared, as the lazy or rebellious individuals have been weeded out. With improved health has come excess vigor to be worked off. Experience in the use of tools has largely overcome the awkwardness of the first few weeks. A pride in accomplishment is quite general. If impatience and dissatisfaction with their lot still exists, they are far less common and serious than they were at first. After all the C.C.C. is not a goal to these young men, but only a stepping stone. 
They take each day as it comes, and in common with the rest of us, hope that better times are coming soon.

From the standpoint of efficiency, the picture is not so bright. The hours of work for enrolled men are forty per week, made up of eight hours per day from Monday to Friday inclusive, with Saturday free unless it may be required to make up time lost through weather conditions or other causes during the five regular working days. The day's work of eight hours includes one hour for lunch and one hour for travel to and from the job with a provision that when travel exceeds a total of one hour a day, the extra time shall be outside the eight hours. In other words, the enrolled men work a minimum of six hours per day, and a maximum of seven hours per day, actually on the job. Applied through five days a week, this means 30 to 35 hours of work, which is considerably less than obtains in most occupations, and far less than is customary in the woods. Compared with the accomplishment of other woods crews, that of the C.C.C. is low for a month or a season.

It seems to be generally agreed that on most tasks the enrolled men of the C.C.C. accomplish less in a unit of time than other workers. Several reasons suggest themselves, including the youth and limited experience of the enrolled men, the lack of incentive where only a few can be promoted, and, possibly, inefficient supervision. Certainly they are in less danger of dismissal than are most workers and there is small reward for outstanding work. On the score of supervision, the diversity of the work projects at the average camp makes it hard to find superintendents and foremen who are qualifed to direct them all.

At the outset time was lost from work projects by the use of men in too elaborate camp construction. That tendency was, however, corrected by the Army when it became apparent. In some of the northern camps time was lost from field work during the early part of the winter while waiting for the arrival of warm clothing. The operating agencies also, in spite of great efforts, were not able to buy tools and equipment rapidly enough, and field work suffered in consequence.

A system which transports men hired in one State to work camps in another is bound to be costly. The inflexible 200 man camp unit has its drawbacks. The operating agencies were not prepared with plans for employing so many men, and in some places were slow in making them. Overhead staffs had to be expanded, by the addition of persons who required training. The regular employees of the Federal and State operating agencies not only had to supervise programs much larger than they had carried before, but also had to act as training units, much as the regular army does in time of war. 
The magnitude of the C.C.C. project created emergencies in the operating agencies, and, no doubt, in the Army also.

We have seen that the announced purposes of the C.C.C. were to relieve unemployment and to restore depleted natural resources. I have already argued that the first purpose has been accomplished admirably, in-so-far as the employment of 300,000 men can relieve the unemployment of many millions. The second purpose is being accomplished with less efficiency than might theoretically be possible, but nevertheless on an unprecedented scale. We, as foresters, should be able to see the bright side of the picture.

Hitherto, intensive silviculture has been almost confined to forest experiment stations. Now samples of it are being created in hundreds of places throughout the country. For the moment the question is not "Will it pay commercially?", but "Are we doing it properly?" Thousands of foresters, including many outstanding ones who in normal times could not be hired for C.C.C. wages, have an unparallelled opportunity to test their theories and apply their knowledge in the woods. If they fail, the profession has no alibi. If they succeed the profession has advancéd immeasurably.

Hundreds of millions of dollars are being spent in physical improvement on forest lands, on roads, trails, buildings, telephone lines, camp grounds, and other things which will assist the protection and administration of the forests and make them serve the public more adequately. We are accomplishing in a year or two improvements which normally could not have been contem. plated for a decade, or perhaps for several decades. It is no time for foresters to bewail the cost and doubt their own plans. They should go forward confidently to do the best job possible with the means at hand.

The Federal Government and the States are cooperating in the administration of the C.C.C. The ideas, plans, and methods which success in one place are likely to receive a trial elsewhere. Participation in a common enterprise should result in mutual understanding and unity of purpose. The result should be more and better forestry.

Three hundred thousand men are being acquainted with forestry through intimate contact with it, and millions of people will watch the results, to whom forestry has been an unknown and abstract thing. Such an opportunity has never come to American foresters before, and may never come again in our time. With people made forestry-conscious to an unprecedented degree, foresters are on trial. They must go forward or drop back. The situation challenges them to exert all the skill and all the leadership of which they are capable. If they demonstrate silviculture in the woods so clearly that the casual observer can appreciate it, their part in the C.C.C. will be a success, whether the efficiency of the enrolled men is $50 \%$ or more, or less. 